\title{
Constitutionale
}

Volume 2 Issue 2, July-December 2021: PP: 125-132

Faculty of Law, Universitas Lampung, Bandar Lampung, Indonesia.

http://jurnal.fh.unila.ac.id/index.php/constitutionale

P-ISSN: 2723-2492 E-ISSN: 2745-9322

\section{The Legitimacy of Presidential Threshold Towards Indonesian Citizens' Democracy and Constitutional Rights}

\author{
Imam Pratama Rifky \\ State Electricity Enterprise, Indonesia \\ imampratama1919@gmail.com
}

Submitted: Jun 24, 2021; Reviewed: Nov 3, 2021; Accepted: Nov 16, 2021

\begin{tabular}{|c|c|}
\hline Article's Information & Abstract \\
\hline $\begin{array}{l}\text { keywords: } \\
\text { Presidential } \quad \text { Threshold; } \\
\text { Democracy; } \quad \text { Constitutional } \\
\text { Right. } \\
\text { DOI } \\
\text { https://doi.org/10.25041/constitu } \\
\text { tionale.v2i2.2445 }\end{array}$ & $\begin{array}{l}\text { A presidential threshold or a threshold for presidential } \\
\text { candidacy dramatically hinders a person's democratic } \\
\text { rights. This is because a person can rightfully nominate and } \\
\text { elect themselves through a political party, which must be } \\
\text { limited due to this system. The Presidential Threshold could } \\
\text { eliminate the fundamental rights of the people in the } \\
\text { constitution, where every citizen has the right to be elected } \\
\text { and to vote. This statement is stated in Article 28(D) } \\
\text { paragraph } 3 \text { of the } 1945 \text { Constitution, later revealed to be } \\
\text { Law No.39 of 1999. With the existence of this presidential } \\
\text { threshold, it is feared that it could injure the law's mandate. } \\
\text { The research aims to determine whether the presidential } \\
\text { threshold injured democracy and the mandate of the } 1945 \\
\text { constitution. } \\
\text { This research uses a normative approach. The research will } \\
\text { focus on the principles, comparisons and history of law. The } \\
\text { presidential threshold will close the space for political } \\
\text { parties to carry the best presidential and vice-presidential } \\
\text { candidates for the community. This automatically kills } \\
\text { democracy, political parties' constitutional rights, and the } \\
\text { peonle's right to choose the hestand auality leaders }\end{array}$ \\
\hline
\end{tabular}




\section{A. Introduction}

Indonesia implements a democratic system of government. Guaranteed by the constitution in Article 1 paragraph 2 of the 1945 Constitution, it states firmly that sovereignty is in the hands of the people and is implemented based on the 1945 Constitution. In a country that implements a democratic system, the people hold the highest power. ${ }^{1}$ As clear evidence that Indonesia is a democratic country, in determining a leader, the Indonesian people can nominate themselves or be nominated, which will be elected simultaneously utilizing general elections. This is clear evidence of democracy which is the human right of every citizen. ${ }^{2}$ Therefore, a country with a democratic constitution will conduct elections to determine a leader both in the legislative and executive spheres at the centre and regions. ${ }^{3}$

According to Ministry of State Apparatus Utilization and Bureaucratic Reform, the presidential threshold in the presidential election will make the party strong. The President to the vice president, if later elected, will have significant political power in parliament, then the threshold will make him strong in the course of presidential government. ${ }^{4}$ Terminology or thresholds in elections are commonly heard and practised in countries that implement a democratic system. ${ }^{5}$ A threshold can also be understood as a system of minimum thresholds for participating in elections. The meaning is to create a threshold in the DPR or legislative for presidential candidates to follow the process in the election. ${ }^{6}$

Implementing a state community's rights is the government's obligation in terms of holding elections and according to a predetermined schedule. ${ }^{7}$ Joseph Shumpeter seconds the theory by stating that elections are an arena and provide a forum for competition or politicians who are already in parliament to protect the rights of citizens. ${ }^{8}$ In the opinion of A. S. S. Tambunan, the General election is a forum for community sovereignty. It is a statement to the form of community rights that grants community rights to representatives so that they can run the wheels of government. ${ }^{9}$

The Presidential Threshold is an effort so that candidate leaders can be selected based on the quality of the candidate leader and based on the party that carries him and not based on which candidate leader has more money. ${ }^{10}$ However, it causes the mandate of the 1945 Constitution and also Article 43 of Law Number 39 of 1999 's implementation, which reads:

"Every citizen has the right to be elected and to vote in general elections based on equal rights through direct, general, free, secret, honest and fair voting in accordance with the

\footnotetext{
1 "Law Number 1 Paragraph (2) Constitution Law 1945".

${ }^{2}$ Nur Hidayat Sardini, Restorasi Penyelenggaraan Pemilu Di Indonesia (Yogyakarta: Fajar Media Press, 2011).

${ }^{3}$ Mukthie Fadjar, "Pemilu Yang Demokratis Dan Berkualitas: Penyelesaian Hukum Pelanggaran Pemilu Dan PHPU," Jurnal Konstitusi 6, no. 1 (2009): 4.

${ }^{4}$ Syahrul Ansyari and Agus Rahmat, “Alasan Pemerintah Pakai Ambang Batas Presiden 25 Persen,” viva.co.id, 2017, https://www.viva.co.id/berita/politik/926377-alasan-pemerintah-pakai-ambang-batas-presiden-25-persen. 5 Robert Dahl and Cary Coglianese, "Democracy and Its Critics," Michigan Law Review 88 (1990), https://doi.org/10.2307/1289333.

${ }^{6}$ Matthew J. Streb, Law and Election Politics, 2nd ed. (New York: Routledge, 2012), https://doi.org/10.4324/9780203121894.

${ }^{7}$ Jimly Asshiddiqie, Pengantar Ilmu Hukum Tata Negara, 5th ed. (Jakarta: PT Raja Grafindo Persada, 2015).

${ }^{8}$ P. Anthonius Sitepu, Studi Ilmu Politik, 1st ed. (Yogyakarta: Graha Ilmu, 2012).

9 Titik Triwulan Tutik, Konstruksi Hukum Tata Negara Indonesia Pasca-Amandemen UUD 1945, 1st ed. (Jakarta: Kencana Prenada Media Group, 2010).

${ }^{10}$ Dwi Rianisa Mausili, "Presidential Threshold Anomaly in Indonesian Government System: Parlementer Reduction in Indonesian Presidential System,” Bappenas Working Papers 2, no. 1 (2019): 31-42, https://doi.org/10.47266/bwp.v2i1.28.
} 


\section{provisions of the legislation"}

Based on the quote above, it can be explained that every citizen has the right and can freely nominate himself and be elected as a leader. Therefore, the author is aware of the gap between the presidential threshold, the mandate of the 1945 Constitution, and the law's implementation. ${ }^{11}$

After the Constitutional Court's decision Number 14/PUU-XI/2013 Reviewing Law No. 422008 regarding the election of State Leaders, a general election has been formed simultaneously. Simultaneous general elections are legislative elections and general elections for the President and vice president and will be conducted simultaneously. Simultaneous general elections are the judicial review of Law No. 422008 concerning presidential and vicepresidential elections. Simultaneous elections begin for the 2019 general election and beyond. ${ }^{12}$

In this article, the author will use a normative research method, focusing on the principles, comparisons and history of the Presidential Threshold and other supporting factors. At the end of this writing, it is hoped that it will answer and provide input on the implementation of this presidential threshold to democracy. ${ }^{13}$

\section{B. Discussion}

\section{Presidential Threshold Definition}

Presidential threshold (threshold) is a regulation of a requirement for a limit of support in the House of Representatives. In this regulation, political parties elections must obtain a total number of votes or seats. The election also nominates a candidate for leader or context to participate in the election of the party concerned or joint from various parties. ${ }^{14}$ The results of the amendments to the 1945 Constitution firmly mandate the election of state leaders to be carried out directly and somewhat by the community. ${ }^{15}$ Now it is a matter of the system and the requirements for the presidential and vice-presidential candidates, especially the threshold requirements that have been and are already in the law on the election of state leaders, namely Law No. 42 of 2008 concerning the election of presidential and vice-presidential candidates.

Aims to create a stable government that will make a system in the legislature and executive run well and not experience any difficulties in taking a policy. Threshold has become a presidential strengthening system through the presidential threshold. Threshold does not conflict with the law because it is fair to all political parties participating in the election. ${ }^{16}$ The Constitutional Court No. 14/PUU-XI/2013 concerning the threshold and a law forming law is approved. The open legal policy of forming laws is interpreted as for lawmakers' freedom to make legal policies. ${ }^{17}$ Therefore, the Constitutional Court has delegated the Threshold for

\footnotetext{
${ }^{11}$ Ulla Fiona and Francis E. Hutchinson, "Indonesia's 2019 Elections: A Fractured Democracy?," Asian Affairs 50, no. 4 (2019): 502-19, https://doi.org/10.1080/03068374.2019.1672400.

12 Putusan Mahkamah Konstitusi No. 14/PUU-XI/2013dalam perkara pengujian Undang-Undang No. 42 Tahun 2008 tentang Pemilihan Umum Presiden dan Wakil Presiden terhadap UUD Negara RI Tahun 1945.

13 Andrew Rosser and Maryke van Diermen, "Law, Democracy and the Fulfilment of Socioeconomic Rights: Insights from Indonesia," Third World Quarterly 37, no. 2 (2016): 336-53, https://doi.org/10.1080/01436597.2015.1108829.

${ }^{14}$ Sigit Pamungkas, Perihal Pemilu (Yogyakarta: Laboratorium Jurusan Ilmu Pemerintahan, 2009).

15 Sodikin Sodikin, "Pemilu Serentak (Pemilu Legislatif Dengan Pemilu Presiden Dan Wakil Presiden) Dan Penguatan Sistem Presidensial,” Jurnal Rechts Vinding: Media Pembinaan Hukum Nasional 3, no. 1 (2014): 19, https://doi.org/10.33331/rechtsvinding.v3i1.54.

${ }^{16}$ I Dewa Made Putra Wijaya, "Mengukur Derajat Demokrasi UU Nomor 42 Tahun 2008 Tentang Pemilihan Umum Presiden Dan Wakil Presiden," Jurnal IUS 1, no. 2 (2017): 27, https://jurnalius.ac.id/ojs/index.php/jurnalIUS/article/download/188/164.

${ }_{17}$ Mardian Wibowo, "Menakar Konstitusionalitas Sebuah Kebijakan Hukum Terbuka Dalam Pengujian UndangUndang," Jurnal Konstitusi 12, no. 2 (2016): 196, https://doi.org/10.31078/jk1221.
} 
Forming Laws policy, namely the government executive and the House of Representatives or Dewan Perwakilan Rakyat (DPR) legislature.

\section{Weaknesses of Implementing Presidential Threshold on Democracy and Constitution}

When formulating the amendments to the 1945 Constitution, it was agreed that the legislature and the government should delegate this threshold. So if the Presidential and Vice Presidential Elections are conducted haphazardly at the same time as the election of members of the House of Representatives, the threshold can still be implemented. Likewise, the threshold can also be abolished if the legislature and the government members want it. ${ }^{18}$

The presidential threshold in simultaneous general elections turns out to have several drawbacks. First, political parties coalition in the process for President and vice president nomination may become transactional party elements. This scheme will weaken or injure the President because the President has been held hostage by a coalition of political parties within the coalition. ${ }^{19}$ Second, at a threshold, it can limit the participation of new political parties, which will compete in the simultaneous elections. Still, they cannot nominate leaders or form coalitions with other parties because of the parliamentary threshold. This can eliminate the rights of political parties in terms of nominating candidates for vice president, even though the 1945 Constitution guarantees this. In the third 1945 constitution amendment, other parties view that the threshold contradicts the 1945 Constitution. The threshold could eliminate the meaning of a fair legal certainty for citizens in the eyes of the law. Provisions regarding the conditions for the nomination of presidential and vice-presidential candidates on the grounds of forming an effective and efficient government have eliminated the right of citizens to choose better and quality leaders. ${ }^{20}$

The Presidential threshold significantly limits the birth of choice in the head of the state election. The people's right to choose is limited to the point where people become ignorant. ${ }^{21}$ A general election regulation or law should provide and will give birth to another option (alternative), likewise in terms of increasing voters' intensity and the quality of candidate leaders. $^{22}$ The Presidential threshold requirement for submitting a presidential candidate has been stated in Law no. 42 of 2008 is not based on reasonable opinion. The threshold for the nomination of presidential and vice-presidential candidates assumes that it is a hidden goal of the big ruling party. The Threshold Regulation in the Law does not make sense because the constitution's mandate has clearly stated that the President who wins the election is based on obtaining fifty per cent of the votes plus one spread over twenty per cent of the province. ${ }^{23}$ There is no evidence of a threshold statement to support a presidential system. Heads of State who come from minor political parties form the cabinet's composition in a coalition. An example is that the Democratic Party was a minority in 2009. Hence, they agreed with the Golkar party to have a joint cabinet even though they previously competed in

\footnotetext{
${ }^{18}$ Nabilla Tashandra, "Pembahasan 'Presidential Threshold' Masih Buntu,” Kompas.com, 2017, https://nasional.kompas.com/read/2017/07/04/16155851/pembahasan.presidential.threshold.masih.buntu?page=a 11 .

${ }^{19}$ Ulla Fionna, "The Trap of Pop-Charisma for the Institutionalization of Indonesia's Post-Suharto Parties," Asian Journal of Political Science 24, no. 1 (2016): 124-41, https://doi.org/10.1080/02185377.2015.1136227.

${ }^{20}$ Thomas P. Power, "Jokowi's Authoritarian Turn and Indonesia's Democratic Decline," Bulletin of Indonesian Economic Studies 54, no. 3 (2018): 307-38, https://doi.org/10.1080/00074918.2018.1549918.

${ }^{21}$ Edward Aspinall et al., "Elites, Masses, and Democratic Decline in Indonesia," Democratization 27, no. 4 (2020): 505-26, https://doi.org/10.1080/13510347.2019.1680971.

${ }^{22}$ Gibran Maulana Ibrahim, "Tolak Presidential Threshold, Demokrat: Membatasi Capres Alternatif," Detiknews, 2017, https://news.detik.com/berita/d-3567236/tolak-presidential-threshold-demokrat-membatasicapres-alternatif.

${ }^{23}$ Sabrina Asril, "Pengamat: 'Presidential Threshold' Konspirasi Jahat Partai Besar,” Kompas.com, 2014, https://nasional.kompas.com/read/2014/01/25/1115549/Pengamat.Presidential.Threshold.Konspirasi.Jahat.Partai. Besar.
} 
the presidential and vice-presidential elections. ${ }^{24}$ The legitimacy of the head of state in a presidential system is not determined by politics in parliament on the election results for members of the DPR. The President and parliament are two different things that have different main functions. The Constitutional Court, together with the General Election Commission and the House of Representatives and People's Consultative Assembly, hinder the optimism of the public vote through the threshold. So the threshold system is what decides the hope of the public's vote, which removes the threshold because the community is optimistic that if the threshold is removed, Indonesia will be much better. ${ }^{25}$

Article 6A paragraph 2 states that before the election is held, the pairs of President and Vice President candidates have been selected and appointed by parties and coalitions of parties. The election procedure has been further elaborated by Law No. 7 of 2017 concerning General Elections in article 222, which states that a candidate pair approved to be appointed from a political party or a combination of several political parties must meet the requirements. This condition is to receive at least twenty per cent of the total members in The House of Representatives or receive twenty-five per cent of the vote absolutely in the General Election of the House of Representatives in the previous period. ${ }^{26}$

The primary character of the presidential system is the separation between the executive and the legislature. ${ }^{27}$ This practice is prevalent in a government. This system is not intended to limit presidential candidates but to facilitate a minimum percentage of votes in the election of President and vice president. ${ }^{28}$

Supposedly, if the legislative elections and the presidential and vice-presidential elections were held together as implicitly contained in Article 22E paragraph 2 in conjunction with Article 6A paragraph 2 of the 1945 Law, the threshold in Article 9 of Law No. 2 of 2008 would lose its legitimacy. Therefore, Article 3 paragraph 5 juncto with Article 9 of Law Number 42 of 2008 differs from its legitimacy. According to Yusril Ihza Mahendra, with the holding of simultaneous elections following the Constitutional Court Number 14/PUU$\mathrm{XI} / 2013$, then the existence of Article 9 of the Presidential Election Law regarding the threshold for the President's Presidential Threshold indirectly should not apply. ${ }^{29}$ Applying the threshold in the upcoming simultaneous general elections will experience serious problems, namely a fat coalition and uncertain thresholds in the future.

The existence of coalition parties raises many new, more serious problems, namely transactional politics, which has weakened the presidential system itself. The country's leaders are held hostage if their policies conflict with the coalition of political parties that support them. Then the problem that is encountered in the Presidential threshold for the upcoming simultaneous elections is (1) the issue of the threshold for presidential nomination requirements, (2) the amount of the Presidential threshold, and (3) the source of the Presidential threshold. So it depends on the legal transactional politics of the formation of the law. They can use the Presidential threshold of twenty per cent, fifteen per cent, or ten per cent. It all depends on the government and the DPR as mandated by the Constitutional Court. Various parties have stated

\footnotetext{
24 Asril.

${ }^{25}$ Chandra Iswinarno, "Rocky Gerung Sebut KPU, MK, DPR Dan MPR Lembaga Pemenggal Optimisme Publik," suara.com, 2020, https://www.suara.com/news/2020/08/04/045000/rocky-gerung-sebut-kpu-mk-dprdan-mpr-lembaga-pemenggal-optimisme-publik.

${ }^{26}$ UU No 7 tahun 2017 tentang Pemilu Pasal 222

${ }^{27}$ Djayadi Hanan, "Memperkuat Presidensialisme Multipartai Di Indonesia: Pemilu Serentak, Sistem Pemilu, Dan Sistem Kepartaian,” Jurnal Universitas Paramadina 13, no. 1 (2017): 1451-75,

http://journal.paramadina.ac.id/index.php/upm/article/view/111.

${ }^{28}$ Widaningsih, "Implikasi Yuridis Atas Putusan Mahkamah Koinstitusi Tentang Penyelenggaraan Pemilihan Umum Serentak Tahun 2019," Jurnal Cakrawala Hukum 19, no. 1 (2014): 93-106, https://doi.org/10.26905/idjch.v19i1.1134.

${ }^{29}$ Putusan Mahkamah Konstitusi No. 108/PUU-XI/2013
} 
that the presidential threshold takes away the rights of the people in choosing quality presidential candidates. There will only be a maximum of five candidate pairs that can participate in the presidential election. But in reality, there will never be five candidates because the political parties are in a coalition so that the coalition of political parties can produce twenty per cent more. Starting from the presidential threshold since 2009, there were only three pairs of presidential candidates competing..$^{30}$ Examples of countries that follow a presidential system are Peru, America, Mexico, Brazil, Kyrgyzstan, and Colombia. These countries implement a system without nomination requirements or thresholds. The presidential threshold is not in their electoral system. Even so, the government systems of these countries are running very well, even more democratic. ${ }^{31}$

\section{Conclusion}

Genuine democratic rights cannot be limited. If you set a presidential threshold, it means that you have blocked someone's democratic rights. Lawmakers must review the presidential threshold regulation system by providing a standard. This standard is formed by opening an ample space for political parties to nominate as President and Vice President. There will be the emergence of qualified candidates for President and Vice President, guaranteeing democracy and the constitutional rights of political parties and the public above any interests.

\section{Bibliography}

\section{A. Journal}

Aspinall, Edward, Diego Fossati, Burhanuddin Muhtadi, and Eve Warburton. "Elites, Masses, and Democratic Decline in Indonesia." Democratization 27, no. 4 (2020): 505-26. https://doi.org/10.1080/13510347.2019.1680971.

Dahl, Robert, and Cary Coglianese. "Democracy and Its Critics." Michigan Law Review 88 (1990). https://doi.org/10.2307/1289333.

Djayadi Hanan. "Memperkuat Presidensialisme Multipartai Di Indonesia: Pemilu Serentak, Sistem Pemilu, Dan Sistem Kepartaian.” Jurnal Universitas Paramadina 13, no. 1 (2017): 1451-75. http://journal.paramadina.ac.id/index.php/upm/article/view/111.

Fadjar, Mukthie. "Pemilu Yang Demokratis Dan Berkualitas: Penyelesaian Hukum Pelanggaran Pemilu Dan PHPU.” Jurnal Konstitusi 6, no. 1 (2009): 4.

Fiona, Ulla, and Francis E. Hutchinson. "Indonesia's 2019 Elections: A Fractured Democracy?" Asian Affairs 50, no. 4 (2019): 502-19. https://doi.org/10.1080/03068374.2019.1672400.

Fionna, Ulla. "The Trap of Pop-Charisma for the Institutionalization of Indonesia's PostSuharto Parties." Asian Journal of Political Science 24, no. 1 (2016): 124-41. https://doi.org/10.1080/02185377.2015.1136227.

Fuqoha, Fuqoha. "Pengisian Jabatan Presiden Dan Presidential Threshold Dalam Demokrasi Konstitusional Di Indonesia.” Ajudikasi: Jurnal Ilmu Hukum 1, no. 2 (2018): 27-38.

\footnotetext{
${ }^{30}$ Fuqoha Fuqoha, "Pengisian Jabatan Presiden Dan Presidential Threshold Dalam Demokrasi Konstitusional Di Indonesia," Ajudikasi : Jurnal Ilmu Hukum 1, no. 2 (2018): 27-38, https://doi.org/10.30656/ajudikasi.v1i2.495.

${ }^{31}$ Abdul Ghofar, "Problematika Presidential Threshold: Putusan Mahkamah Konstitusi Dan Pengalaman Di Negara Lain,” JurnaI Konstitusi 15, no. 3 (2018): 480.
} 
https://doi.org/10.30656/ajudikasi.v1i2.495.

Ghofar, Abdul. "Problematika Presidential Threshold: Putusan Mahkamah Konstitusi Dan Pengalaman Di Negara Lain.” JurnaI Konstitusi 15, no. 3 (2018): 480.

Power, Thomas P. "Jokowi's Authoritarian Turn and Indonesia's Democratic Decline." Bulletin of Indonesian Economic Studies 54, no. 3 (2018): 307-38. https://doi.org/10.1080/00074918.2018.1549918.

Rianisa Mausili, Dwi. "Presidential Threshold Anomaly in Indonesian Government System: Parlementer Reduction in Indonesian Presidential System." Bappenas Working Papers 2, no. 1 (2019): 31-42. https://doi.org/10.47266/bwp.v2i1.28.

Rosser, Andrew, and Maryke van Diermen. "Law, Democracy and the Fulfilment of Socioeconomic Rights: Insights from Indonesia." Third World Quarterly 37, no. 2 (2016): 336-53. https://doi.org/10.1080/01436597.2015.1108829.

Sodikin, Sodikin. "Pemilu Serentak (Pemilu Legislatif Dengan Pemilu Presiden Dan Wakil Presiden) Dan Penguatan Sistem Presidensial.” Jurnal Rechts Vinding: Media Pembinaan Hukum Nasional 3, no. 1 (2014): 19. https://doi.org/10.33331/rechtsvinding.v3i1.54.

Wibowo, Mardian. "Menakar Konstitusionalitas Sebuah Kebijakan Hukum Terbuka Dalam Pengujian Undang-Undang." Jurnal Konstitusi 12, no. 2 (2016): 196. https://doi.org/10.31078/jk1221.

Wijaya, I Dewa Made Putra. "Mengukur Derajat Demokrasi UU Nomor 42 Tahun 2008 Tentang Pemilihan Umum Presiden Dan Wakil Presiden.” Jurnal IUS 1, no. 2 (2017): 27. https://jurnalius.ac.id/ojs/index.php/jurnalIUS/article/download/188/164.

Widaningsih. "Implikasi Yuridis Atas Putusan Mahkamah Koinstitusi Tentang Penyelenggaraan Pemilihan Umum Serentak Tahun 2019.” Jurnal Cakrawala Hukum 19, no. 1 (2014): 93-106. https://doi.org/10.26905/idjch.v19i1.1134.I

\section{B. Book}

Asshiddiqie, Jimly. Pengantar Ilmu Hukum Tata Negara. 5th ed. Jakarta: PT Raja Grafindo Persada, 2015.

Pamungkas, Sigit. Perihal Pemilu. Yogyakarta: Laboratorium Jurusan Ilmu Pemerintahan, 2009.

Sardini, Nur Hidayat. Restorasi Penyelenggaraan Pemilu Di Indonesia. Yogyakarta: Fajar Media Press, 2011.

Sitepu, P. Anthonius. Studi Ilmu Politik. 1st ed. Yogyakarta: Graha Ilmu, 2012.

Streb, Matthew J. Law and Election Politics. 2nd ed. New York: Routledge, 2012. https://doi.org/10.4324/9780203121894.

Tutik, Titik Triwulan. Konstruksi Hukum Tata Negara Indonesia Pasca-Amandemen UUD 1945. 1st ed. Jakarta: Kencana Prenada Media Group, 2010.

\section{Regulations}

1945 Constitution of the Republic of Indonesia

Law Regulations Number 39 of 1999

Law Regulations Number 42 of 2008

Law Regulations Number 7 of 2017

Constitutional Court Decision Number 14-XI/2013

\section{Others}


Ansyari, Syahrul, and Agus Rahmat. "Alasan Pemerintah Pakai Ambang Batas Presiden 25 Persen.” viva.co.id, 2017. https:/www.viva.co.id/berita/politik/926377-alasanpemerintah-pakai-ambang-batas-presiden-25-persen.

Asril, Sabrina. "Pengamat: 'Presidential Threshold' Konspirasi Jahat Partai Besar." Kompas.com, 2014. https://nasional.kompas.com/read/2014/01/25/1115549/Pengamat.Presidential.Threshold .Konspirasi.Jahat.Partai.Besar.

Ibrahim, Gibran Maulana. "Tolak Presidential Threshold, Demokrat: Membatasi Capres Alternatif." Detiknews, 2017. https://news.detik.com/berita/d-3567236/tolak-presidentialthreshold-demokrat-membatasi-capres-alternatif.

Iswinarno, Chandra. "Rocky Gerung Sebut KPU, MK, DPR Dan MPR Lembaga Pemenggal Optimisme Publik.” suara.com, 2020. https://www.suara.com/news/2020/08/04/045000/rocky-gerung-sebut-kpu-mk-dpr-danmpr-lembaga-pemenggal-optimisme-publik.

Tashandra, Nabilla. "Pembahasan 'Presidential Threshold' Masih Buntu.” Kompas.com, 2017. https://nasional.kompas.com/read/2017/07/04/16155851/pembahasan.presidential.thresh old.masih.buntu?page=all . 